[seção Contextos]

\title{
AUTORRETRATO ESCOLAR NÃO COMO FOI, MAS COMO SENTI - EXTRATOS DO QUE DOU CONTA DE CONTAR
}

\section{AUTORRETRATO ESCOLAR NO CÓMO FUE, SINO CÓMO ME SENTÍ: EXTRACTOS DE LO QUE PUEDO DECIR}

\author{
Sandro Ferreira Pinto 1 \\ ${ }^{1}$ Mestrando do Programa de Pós-Graduação em Estudos de Cultura e \\ Território da Universidade Federal do Tocantins - UFT. \\ E-mail: sandrofpdefensor@gmail.com
}

\begin{abstract}
Resumo: Trata-se de relato autobiográfico escolar, produzido originalmente na disciplina de metodologia do programa de pós-graduação em cultura e território - PPGCULT, da Universidade Federal do Tocantins - UFT. São aproximadamente 37 (trinta e sete anos) de história pessoal envolvendo a formação escolar e acadêmica, sinteticamente narrada através dos episódios mais marcantes em minha formação. Uma tentativa de descrever experiências, sensações e significações dos estudos em minha vida, que culminam no esboço de um autorretrato.
\end{abstract}

Resumen: Se trata de un informe escolar autobiográfico, elaborado originalmente en la disciplina de metodología del programa de posgrado en cultura y territorio - PPGCULT, de la Universidad Federal de Tocantins - UFT. Son aproximadamente 37 (treinta y siete años) de historia personal que involucran formación escolar y académica, narrados sintéticamente a través de los episodios más llamativos de mi formación. Un intento de describir vivencias, sensaciones y significados de estudios en mi vida, que culminan en el esbozo de un autorretrat.

Vim ao mundo no dia 20 de junho do longínquo ano de 1977. Nasci quase junto com o inverno, em uma típica manhã gelada curitibana, às 9 horas e 07 minutos, na região metropolitana de Curitiba, no Município de Piraquara, no Paraná. Nada de especial neste dia e só sei exatamente a hora em que nasci porque essa informação é perguntada no site personare para fazer mapa astral. Sou muito supersticioso.

Cresci no seio de uma família humilde, com meus pais e uma irmã caçula, três anos mais nova. Meu pai trabalhava na extinta RFFSA e passava a semana fora de casa viajando. Morava num vagão de trem e percorria a região fazendo manutenção em postes na beira da estrada de ferro. $\mathrm{Na}$ inocência da infância considerava fenomenal morar num trem e viver viajando. Minha mãe, antes empregada doméstica, após meu nascimento e em razão de problemas de saúde 
deixou o trabalho externo remunerado para se dedicar aos cuidados da casa.

Meus pais sempre se empenharam para nos ofertar uma boa educação e antes mesmo de iniciar na escola compravam revistas de colorir e cadernos para incentivar os estudos. Recordo um caderno quadriculado que ganhei com 05 (cinco) anos de idade aproximadamente. Logo após receber o presente, desandei a escrever nele os números em ordem crescente. Depois de um tempo, todo orgulhoso de mim mesmo, fui mostrar para minha mãe já com os dedos cansados - havia escrito do 1 ao 100. Esse momento me marcou porque depois da euforia por escrever até a primeira centena fui tomado por uma frustração. Percebi que não havia terminado. Faltava o 101, 102, o mil, o milhão, etc. Começava a me deparar com o incompreensível infinito, perplexidade que me acompanharia o resto da vida.

Toda minha formação escolar aconteceu em escola pública, exceto cursos pré-vestibular que fiz graças ao emprego que possuía. Iniciei a escolarização entre os seis e sete anos na pré-escola e conclui a primeira parte do ensino fundamental com apenas um incidente. Na terceira série (quarto ano) minha mãe foi convocada a escola por conta de uma briga na qual havia me envolvido. Foram vias de fato simples entre colegas, mas a relevância do momento está no motivo da contenda. Brigamos em razão da eleição de representante de turma e eu nem candidato era. A política começava a se manifestar em minha vida escolar.

No ensino fundamental II troquei de escola e fui estudar no "ginásio" (era assim que chamávamos). Até então a única disciplina que me fascinava era a matemática - especialmente depois de conhecer a geometria. Não entedia, por exemplo, a fórmula da diagonal do quadrado. Até sabia a fórmula, mas o resultado sempre exibia uma dízima periódica - que é um número infinito. Como pode o interior do quadrado ser infinito se o próprio quadrado não o é? O professor explicava, mas eu não entendia nada e ficava muito chateado. No fundo a questão não era só matemática e depois de muito tempo revivi o paradoxo ao estudar filosofia. Era novamente o infinito me inquietando, agora na aurora da adolescência. Mas se não sabia matemática, imagina filosofia.

Admiro muito meus professores, pois acredito que eu não era um aluno muito fácil de ensinar. Um dia, no auge de minha petulância adolescente (e ignorância, diga-se) me recusei a uma tarefa de educação artística porque não a considerava arte e não sendo arte não via nenhum sentido em realizar o trabalho determinado pela professora. Lá foi minha mãe na Escola pela segunda vez. 
Aos quatorzes anos terminava a oitava série (nono ano) e se avizinhava o segundo grau - hoje ensino médio. Queria fazer magistério, mas meu pai queria que estudasse no CEFET-PR (atualmente o Instituto Federal). Meu pai queria o ensino técnico por acreditar que me possibilitaria melhores chances de emprego no futuro. Minha mãe - sempre mediadora - convenceu-me a prestar o exame.

Aprovado na seleção do CEFET-PR, entrei no curso de edificações. Passei a estudar no centro de Curitiba e por volta dos 15 anos começava a andar "sozinho" por toda a capital paranaense. Claro que não andava em toda a cidade, mas para um piá crescido em uma pequena cidade periférica, o centro de Curitiba representava um extraordinário mundo a ser explorado. O período foi profícuo em experiências pessoais e nessa época fui iniciado em muitas práticas. Por exemplo, foi no CEFETPR que conheci o movimento estudantil. Engrossando as fileiras dos "caras pintadas", nas passeatas "Fora Collor" na década de 90, empolguei-me e ingressei na juventude do PSTU.

Aprendi muito sobre muitas coisas nesse período - exceto sobre edificações. Dizer que estudava no CEFET-PR ou que frequentava as aulas no CEFET-PR pode induzir o leitor a erro - mais realístico contar apenas que estava matriculado no CEFET-PR. Em um ano e meio não consegui passar em nenhuma disciplina técnica, embora fosse aprovado nas disciplinas de núcleo comum. Então minha mãe convenceu meu pai a me transferir para outra escola e atender meu desejo de cursar o magistério.

Voltei a estudar em Piraquara, no Colégio Estadual Mário Braga, unidade recém inaugurada e fruto da reforma de parte de uma obra pública abandonada pelo governo. Um colégio que já nasceu repleto de histórias. Éramos em minha turma dezenas de alunas e só dois alunos. O recorte de gênero atrelado ao ofício de professor - ou melhor, de professora, era fortíssimo.

Intensifiquei minha atuação na política estudantil, formamos um grêmio no Colégio e ocupamos os outros pavilhões da obra abandonada para reivindicar o espaço para a Escola. Não conseguimos nada de efetivo, mas as articulações e ações contribuíram em minha formação. Nessa época já havia me desentendido com o pessoal do PSTU e iniciava minha jornada na União da Juventude Socialista - a famosa UJS. Criamos uma UMES em minha cidade - união municipal de estudantes secundaristas e me orgulho de ter sido eleito seu primeiro presidente.

$\mathrm{Na}$ sequência rompi com a UJS porque me recusava a filiar ao $\mathrm{PC}$ do $\mathrm{B}$. A 
UJS não é partidária e ninguém te obriga a se filiar a partido, mas é incontestável que PC do B exercia fortíssima influência na entidade e dominava os quadros de lideranças. Após o rompimento me aproximei do Partido dos Trabalhadores. Havia alguns grupos internos de juventude no partido, como o FERA - Força Estudantil Revolucionária Alternativa, por exemplo, e outros com pequenas variações ideológicas - diferenças quase incompreensíveis para mim, inclusive.

Tudo ia muito bem, exceto os estudos. Muito envolvido com a política estudantil quase não me dedicava às disciplinas e por pouco não reprovei naquele ano. Também comecei a ter problemas em casa por causa de relatos que chegavam sobre nossa atuação no movimento, especialmente depois de planejarmos ocupar um terminal de ônibus da cidade durante um protesto por "passe livre para estudantes". A situação chegou ao limite quando, após redigir e distribuir um panfleto injurioso contra um professor do PSDB, tivemos - eu e um colega, que prestar esclarecimentos para a autoridade policial.

A paciência de meus pais beirava o esgotamento. Agravava a situação o fato do curso de magistério ser matutino e ainda faltavam 02 (dois) anos para conclusão. Então efetuei uma nova transferência de colégio e para um curso noturno, no intuito de trabalhar e amainar um pouco as cobranças em casa. E assim acabei removido quase que compulsoriamente para o curso de administração de empresas, turno da noite e noutro Colégio. Só não conseguia arrumar emprego.

Também já tinha sido deligado do PT por não concordar com as posições de alguns políticos muito influentes no movimento estudantil. Passei a militar então na Juventude Socialista do PDT, conquistado pela retórica do Brizola. Lembro que mesmo sem ser universitário, viajei patrocinado por doações a Belo Horizonte para participar de um Congresso da União Nacional dos Estudantes somente com o objetivo de apoiar os colegas do Partido. Acho que nunca briguei tanto em minha vida - com palavras e atos. A UNE realmente não é para principiantes.

Então, uma guinada em minha vida. Minha namorada, também militante e mãe de uma menina que tenho até hoje como filha, contou estar grávida. Foi uma etapa muito difícil porque ambos éramos além de muito jovens, pobres.

A responsabilidade me fez voltar os olhos para os estudos e outro problema surgia. Fui informado que duas matérias cursadas no CEFET-PR não tinham sido aceitas pela Secretaria de Educação para fins de compensação durante os processos de transferências. Com essa notícia e de acordo com o currículo do colégio em que 
estava estudando, precisaria ainda de mais 03 (três) anos para concluir o curso e eu já estava há 4 anos no ensino médio.

Era inviável esperar tanto tempo e não estava disposto a correr o risco de prestar exames de equivalência. Então, depois de iniciar e não terminar edificações, magistério e administração de empresas, já caminhando para os 19 anos e com um filho e uma enteada, rumei para a Educação de Jovens e Adultos - EJA, arrumei um emprego e em 02 (dois) anos finalmente conclui o ensino médio. No EJA também encerrei minha vida na política estudantil, após ser expulso do PDT por divergências com lideranças locais. Passei a encarar a política com uma perspectiva diferente e decidi lutar fora das agremiações partidárias.

Com meu filho e sua irmã pequenos, auferindo apenas um salário - mínimo mensal, sentia que precisava avançar na qualificação. Quando menino, gostaria de estudar muitas coisas - matemática, ciências sociais, filosofia, história e direito. Porém a carência de recursos me impunha um só curso, a opção foi o direito, e uma só faculdade - a pública. Então, após muito esforço e duas tentativas, fui aprovado no primeiro vestibular do milênio na Universidade Federal do Paraná - PR e no ano 2000 ingressei no curso de direito. Lembro bem da data porque temíamos o "bug do milênio" nos computadores da Universidade.

Dificuldades financeiras, desemprego, dedicação para concursos públicos, divórcio, um novo casamento, problemas de saúde na família e o nascimento prematuro de minha filha em 2006, foram alguns dos percalços que contribuíram para que minha graduação demorasse 11 (onze) anos até a formatura. Nesse período só não fui jubilado por que em 2007 prestei novo vestibular e consegui ser aprovado novamente renovando minha matrícula.

Já era servidor no Tribunal Regional Eleitoral do Paraná quando me tornei Bacharel em Direito em 2011, mas um projeto me movia desde a faculdade - defender pessoas. Decidi então estudar para ser Defensor Público e segui nessa empreitada até ser aprovado. Depois de algumas reprovações, algumas extremamente dolorosas como em 2012, no Rio de Janeiro, consegui aprovação nas Defensorias Públicas do Tocantins, do Sergipe, do Amazonas e do Paraná. Cheguei a trabalhar por pouco tempo nestes dois últimos Estados até que no dia 02 de dezembro de 2013 tomei posse na Defensoria Pública do Tocantins, como primeiro colocado, realizando meu grande sonho, pois durante a preparação o Tocantins, ao lado do RJ, havia se transformado em meta. 
Atualmente, no derradeiro 2020 - neste estranho 2020 pandêmico, após 07 (sete) anos da realização do sonho profissional, vivo a retomada de outro sonho nutrido lá nos bancos da Universidade - o Mestrado. Em 2019 ingressei no Programa de Pós-Graduação em Estudos de Cultura e Território - PPGCULT, da Universidade Federal do Tocantins.

Um novo sonho cuja concretização ainda engatinha. Um sonho que ensejou a produção deste relato, hoje um apanhado de emoções retrospectivas compartilhadas, outrora uma tarefa disciplinar nas aulas de metodologia, com os inesquecíveis e queridíssimos professores Sariza e Dernival. Um sonho que talvez me constitua e mantenha, pois desde que me reconheço (se é que me conheço) desde os seis anos de idade, estou estudando e sonhando.

Durante os 11 (onze) anos na Faculdade nunca tranquei matrícula -em todos os anos tentei concluir. Na sequência, vieram os estudos concurseiros e mesmo depois de aprovado continuei estudando. Nesse tempo, revisitando as preferências disciplinares da faculdade, para não dizer paixões, concluí duas especializações uma em Criminologia e a outra em Filosofia do Direito. E sigo sonhando e estudando neste instante na Universidade Federal do Tocantins.

Talvez seja o estudo em mim uma compulsão, talvez um refúgio de mim mesmo, um alento de paz ou quem sabe um lugar de liberdade onde minha consciência se permita voar. Não sei - só sei que não quero e não vou parar de estudar. Encerro, mas não sem antes alertar - o que escrevi aqui não descreve um eu inteiro, é só o recorte, um eu escolar, só um eu que dei conta de contar.

Submetido: 10/12/2020

Aprovado: 20/12/2020 